\title{
Italy's labour market reforms of 2012: did they reduce unemployment?
}

\section{Gabriele Piazza and Martin Myant}

Working Paper 2015.11

\section{etul.}




\section{Italy's labour market reforms of 2012: did they reduce unemployment?}

Gabriele Piazza and Martin Myant

Working Paper 2015.11

european trade union institute 
Martin Myant is senior researcher and head of unit for European Economic, Employment and Social Policy at the European Trade Union Institute (ETUI) in Brussels.

Gabriele Piazza recently graduated from the LSE, previously at ETUI, currently a research intern at the Social Market Foundation.

Brussels, 2015

( ) Publisher: ETUI aisbl, Brussels

All rights reserved

Print: ETUI Printshop, Brussels

D/2015/10.574/56

ISSN: 1994-4446 (print version)

ISSN: 1994-4454 (electronic version)

The ETUI is financially supported by the European Union. The European Union is not responsible for $\star_{\star \star \star \star *}^{*}$ any use made of the information contained in this publication. 


\section{Contents}

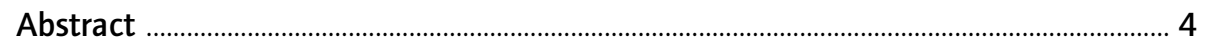

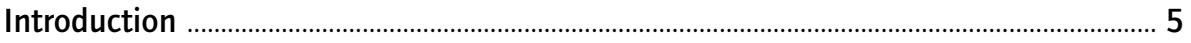

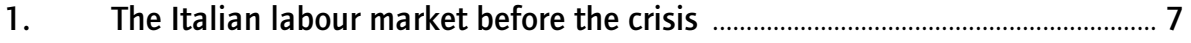

2. The Italian labour market during the crisis ..................................................... 12

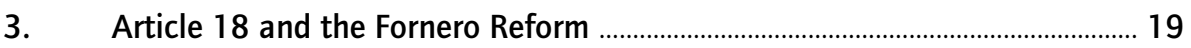

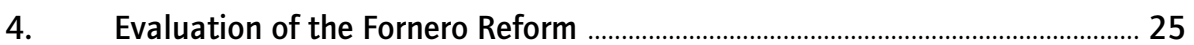

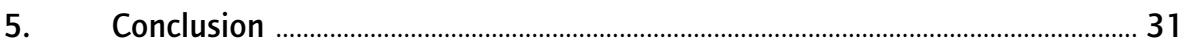

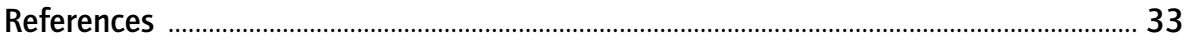




\section{Abstract}

In 2012 Italy, under pressure from the European Central Bank, introduced a package of labour-market reforms. One particularly controversial measure was a reduction in the previously substantial protection against dismissal enjoyed by permanent employees, relaxation of which was billed as a means of reducing unemployment and labour-market dualism. Earlier reforms brought in during the years before 2008 had created scope for big increases in part-time and temporary employment contracts. Yet these measures had failed to increase aggregate employment, and available data indicate that they coincided with the conversion of irregular into regular employment and with the replacement of permanent by fixed-term employees. There is extremely little evidence to support claims that protection for permanent employees affected employment levels. The high extent of regional differences across Italy would seem to be an indicator of the rather low significance of the legislative framework in explaining employment and unemployment levels. The labour-market response to the crisis also varied between regions. The reforms of 2012 were not followed, in the short period for which adequate data are available, by increases in employment. Other factors evidently outweighed any impact they might have exerted in that direction. Nor did the reforms lead to any redressing of permanent to the detriment of atypical contracts. Instead, the trend was for the newly employed to be recruited on the basis of irregular contracts in the absence of any evidence that these would be a stepping stone into subsequent permanent employment. 


\section{Introduction}

Given the increase in unemployment levels in EU countries since the crisis of 2008, their reduction has become a prime goal of policy makers. A consistent view from the European Commission has been that reducing unemployment depends on greater labour market flexibility which can be achieved in large measure - so the Commission claims - by facilitating dismissals. Such flexibility has been presented also as a step towards reducing dualism in labour markets insofar as it would result in a narrowing of the gap, in terms of employment protection levels, between workers on standard and those on nonstandard contracts. ${ }^{1}$

In Italy labour market reforms following the crisis marked a change from an earlier emphasis - in the so-called Treu and Biagi reforms - on increasing flexibility at the entry level by creating and promoting contractual arrangements with lower employment protection. A further aim of the more recent changes has been to facilitate the dismissal of those already in employment.

The most important piece of legislation in this direction before 2015 was Law no. 92 of 28 June 2012, also known as the Fornero reform, that effectively reduced the cost of dismissing individual workers employed on permanent contracts. The important change was to Article 18 of Italy's 1970 Workers' Statute (L. 300/19). This article gave workers found to have been unfairly dismissed, whether for unjustified economic or unjustified subjective disciplinary reasons, the right to choose between reinstatement and compensation ${ }^{2}$ in addition to the salaries unpaid from the day of the unlawful dismissal up to the reinstatement, with no upper limit. After the implementation of the Fornero Reform on 18 July 2012, the employee found to have been dismissed in the absence of a 'justified economic reason' could no longer be reinstated ${ }^{3}$ but would merely be awarded compensation equal to 12-24 months' salary.

Analysing the impact of changes to Article 18 is valuable for two substantive reasons: first, it was one of the demands of the ECB to the Italian government in exchange for an informal commitment to buy national bonds to alleviate the

1. For discussion and criticism of the theory behind this, see Horwitz and Myant (2015).

2. This is equivalent to 15 months of his or her salary.

3. Reinstatement continues to apply in cases where the dismissal was motivated by discrimination. It applies also to dismissals for disciplinary reasons if the alleged fact did not occur or if collective agreements contain provision for lesser sanctions. With regard to economic reasons, reinstatement still applies if the economic reason is 'manifestly nonexistent'. 
debt crisis it was experiencing (Trichet and Draghi 2011) and was thus seen as external interference in national policy; secondly, it had been at the centre of both academic and political debate for two decades. Indeed, its abrogation had been the subject of a referendum in 2000 and its extension to firms with fewer than 15 employees the subject of another referendum in 2003. Neither referendum had reached the quorum required for adoption of the proposed measure.

Arguably more substantial reforms followed in 2015, but it is too early to analyse their effects. The aim of this paper is to assess whether and to what extent the earlier changes brought in by the Fornero reform with regard to the individual dismissal of workers employed on permanent contracts did actually contribute to the stated goals of reducing unemployment and tackling the perceived problem of dualisation. Did they, in other words, serve to reduce the incentives associated with non-standard employment contracts which have traditionally entailed lower employment protection?

It would not be justified to draw conclusions on the effects of reforms from aggregate employment or unemployment figures partly because of the short time period since implementation and partly because of the likely influence of other factors alongside employment protection legislation. The key evidence therefore relates to the employment structure, meaning the distribution of the different types of contractual arrangements, regular and atypical. As the aim of the reform was to provide incentives for the use of regular contracts by lowering protection against individual dismissal, the question is whether or not there has been a reduction in the numbers of atypical contracts and of employees covered by them and an increase in the numbers of regular contracts and permanent employees.

The main argument of this paper is that labour market reforms focused on promoting flexibility by lowering employment protection in the case of individual dismissals of workers employed on permanent contracts had no significant impact on the labour market. More specifically, the Fornero reform did not achieve its intended goal of 'recalibrating' the labour market, let alone reducing unemployment. There has been no tangible move by employers towards favouring regular rather than temporary contracts.

In order to pursue the aforementioned aims, the rest of the paper will be structured as follows. In Section 1 the problems of the Italian labour market prior to the crisis and the reforms adopted to tackle them will be examined. Section 2 will illustrate the impact of the crisis on employment and unemployment levels in Italy, which will be compared to those in other EU countries. Section 3 will briefly outline the Fornero Reform and the controversy behind Article 18. Section 4 will assess the impact of the reforms on the employment structure by looking at the incidence of different contractual arrangements. Section 5 will conclude by discussing the policy and theoretical implications of the findings. 


\section{The Italian labour market before the crisis}

The Fornero reform came in the wake of earlier attempts to adjust the statutory framework governing the Italian labour market, notably the so-called Treu (1997) and Biagi (2003) reforms. These were billed as addressing structural weaknesses behind slow growth and rising unemployment from the late $1970 \mathrm{~s}$ which became particularly acute in the 1980 (Da Roit et al. 2013; Jessoula et al. 2010: 563). During the 1980s, the attempts to tackle unemployment had been focused on reducing the labour supply; these were judged successful but financially unsustainable in the long run (Graziano 2007: 547). However, the unemployment rate remained high and in the mid-1990s the employment rate - 51.1\% in 1995 - was considerably below the EU average (Eurostat, lfsi_emp_a). Additionally, Italy differed significantly from other industrialised economies in that here 'regular dependent employment' represented a comparatively low portion of total employment (57\%). Most significantly, Italy had a high share of self-employed, 32\% in 1997 against an EU average of 17\% (Lodovici 2000: 274; Tompson 2009: 251). At the same time, the use of nonstandard contractual arrangements was 'all but unknown prior to the 1990s' (Tompson 2009: 253). By 1996, employees on temporary contracts represented $7.4 \%$ of the total number of employees and demand for these types of employment was said to be on the rise and increasingly met by circumventing regulations or operating in the shadow economy (Garibaldi and Taddei 2013: 21).

The negative performance of the labour market was attributed to a particular aspect of its employment protection legislation which stood out as offering unusually strong protection by European standards, albeit applying in practice to only $44 \%$ of workers at the time. The feature in question was the restrictions on firing employees on regular contracts (Tompson 2009: 251). It is against this background that the two aforementioned reforms - Treu and Biagi - were introduced. Despite being implemented by a centre-left and centre-right government respectively, they shared the aim of introducing 'flexibility at the margins'; in other words, they established or incentivised more flexible contractual arrangements entailing lower dismissal costs (Tompson 2009: 251). This was also the most politically viable solution, given the strong opposition by trade unions to changes to regular contracts (Jessoula et al. 2010).

The Treu Reform created space for 'atypical flexible contracts'. More specifically, the public monopoly on placement services was abolished (so that private temporary work agencies could operate fully) and measures were introduced to increase the use of part-time work. Fixed-term contracts were no longer automatically converted into regular contracts and regulations for 
new apprenticeships and work-in-training contracts (Contratto diformazione lavoro) were eased (Tompson 2009).

In 2003, the Biagi reform introduced various other forms of non-standard employment - on-call jobs, job-sharing and project work (co.co.pro replacing co.co.co.) - with the stated goals of reducing employment in the shadow economy and increasing employment among women, young people and older workers (Garibaldi and Taddei 2013: 20).

After the implementation of the Treu Reform and up to the outbreak of the crisis, labour market figures improved. In 2007, notwithstanding the regional disparities mentioned in Section 2, the unemployment rate in Italy was 6.1\%, lower than the EU28 average of 7.2\% (Eurostat, une_rt_a). Labour market participation among the $15-64$ age group had risen to $58.6 \%$ by 2007 , an improvement that left it still very significantly below the EU28 average of $65.2 \%$ (Eurostat, lfsi_emp_a).

The argument linking increased employment to changes in labour law can find apparent support from the data in Table 1. Between 1999 and 2007, employment increased by 2.53 million, while the number of employees on part-time contracts increased by 1.486 million units and the number of temporary employees grew by 819,600 . Table 2 shows the sectoral breakdown of employment changes. The biggest gain in this period took place in services with an increase in employment of 2.73 million. Public administration and manufacturing recorded declines, the latter being in line with similar developments in other European economies.

Table 1 Total, Temporary and Part-time employees: change 1999-2007 (in '000s)

\begin{tabular}{|l|r|r|r|r|}
\hline & $\mathbf{1 9 9 9}$ & $\mathbf{2 0 0 3}$ & $\mathbf{2 0 0 7}$ & Change 1999 - 2007 \\
\hline Total Employment & $20,691.6$ & $22,054.20$ & $23,221.80$ & $2,530.20$ \\
\hline Temporary employees & $1,442.20$ & $1,519.70$ & $2,261.80$ & 819.60 \\
\hline Part-time employees & $1,582.30$ & $1,847.00$ & $3,069.10$ & $1,486.80$ \\
\hline
\end{tabular}

Source: Istat, own calculations

Table 2 Changes in Employment (in '000s), by selected sectors, 15-64 age group, Italy

\begin{tabular}{|l|r|r|r|r|}
\hline \multirow{2}{*}{} & \multicolumn{2}{|c|}{ Total Employment } & \multicolumn{2}{|c|}{ Change } \\
\cline { 2 - 5 } & $\mathbf{1 9 9 9}$ & $\mathbf{2 0 0 7}$ & All (\%) & All \\
\hline Manufacturing (C) & $4,869.70$ & $4,769.40$ & -2.06 & -100.30 \\
\hline Construction (F) & $1,500.40$ & $1,951.20$ & 30.05 & 450.80 \\
\hline Services (G-K) & $12,404.70$ & $15,135.60$ & 22.02 & 2730.90 \\
\hline Public Administration (O) & $1,714.40$ & $1,447.70$ & -15.56 & -266.70 \\
\hline Education (P) & $1,486.80$ & $1,623.90$ & 9.22 & 137.10 \\
\hline Health (Q) & $1,279.30$ & $1,595.10$ & 24.69 & 315.80 \\
\hline
\end{tabular}

Note: Sector classification NACE1.1.

Source: Eurostat (Ifsq_egana), own calculations 
These figures would therefore be consistent with the increase in employment in services having been made possible by the increasing numbers of workers employed on non-standard contracts. However, Meardi (2012) argues that the rise in employment figures is the result less of new job creation than of regularisation of previously informal employment. A substantial share of the employment growth between 2000 and $2005(968,306)$ can be ascribed to the 638,000 newly regularised migrants that left the shadow economy and (thanks to Law 189/02, also known as Bossi-Fini) registered as regular employees during the 2002-2004 period (ISTAT 2005). The reported reduction of employment in the shadow economy from $13.8 \%$ in 2001 to $12.0 \%$ in 2005 would support the claim that the rise of employment in this period is at best due only partly to the creation of actual jobs (MEF 2011).

Figure 1 compares recorded new job creation with regularisation of migrants over the 2001- 5 period. The apparent mismatch in timing can be explained by the fact that these workers may have been added to the year in which they were originally hired but appear as regularised workers only once the lengthy administrative process has ended (Anastasia et al. 2004: 127). This, then, broadly explains the increase in total numbers employed, although questions remain as to exactly where these newly formalised workers appear in the detailed sectoral employment statistics.

Figure 1 Change in total employees, work permits and regularised migrant workers (in '000s)

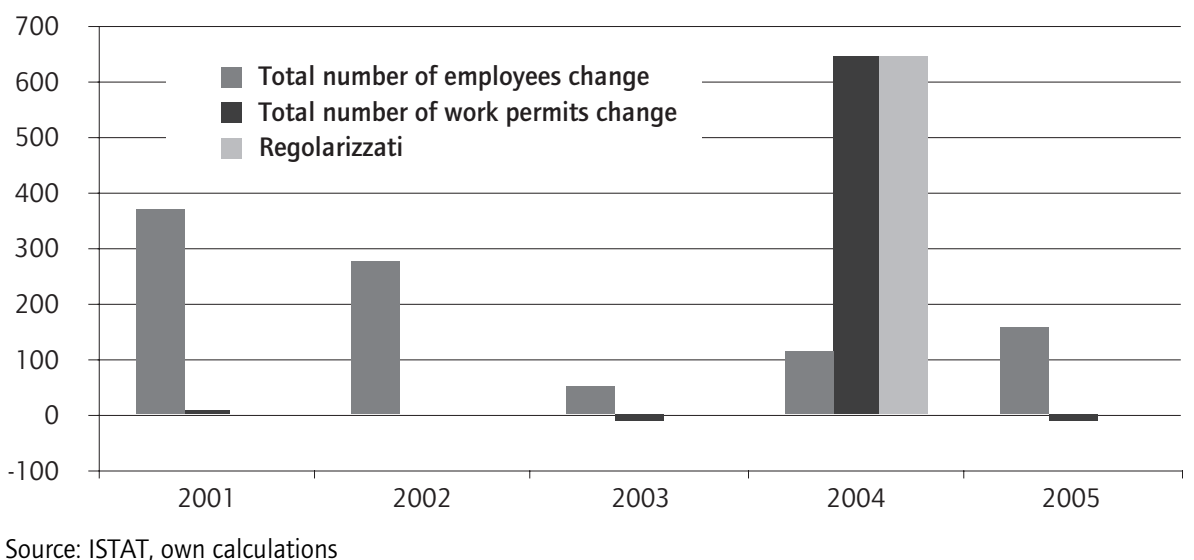

Surprisingly, although the increase in more flexible contractual arrangements did coincide with increasing employment among female workers, very little change was recorded in the employment rate of young workers. As shown in Figure 2, the incidence of temporary contracts is higher among those aged 1524 (43.2\% on temporary contracts out of total employment in 2007) than in other age cohorts and it began to increase after the Biagi reform. However, as the employment rate among this age group remained stable, it would appear that permanent jobs were replaced by temporary ones without any net employment creation. 
Figure 2 Temporary employees as percentage of the total number of employees by selected age groups

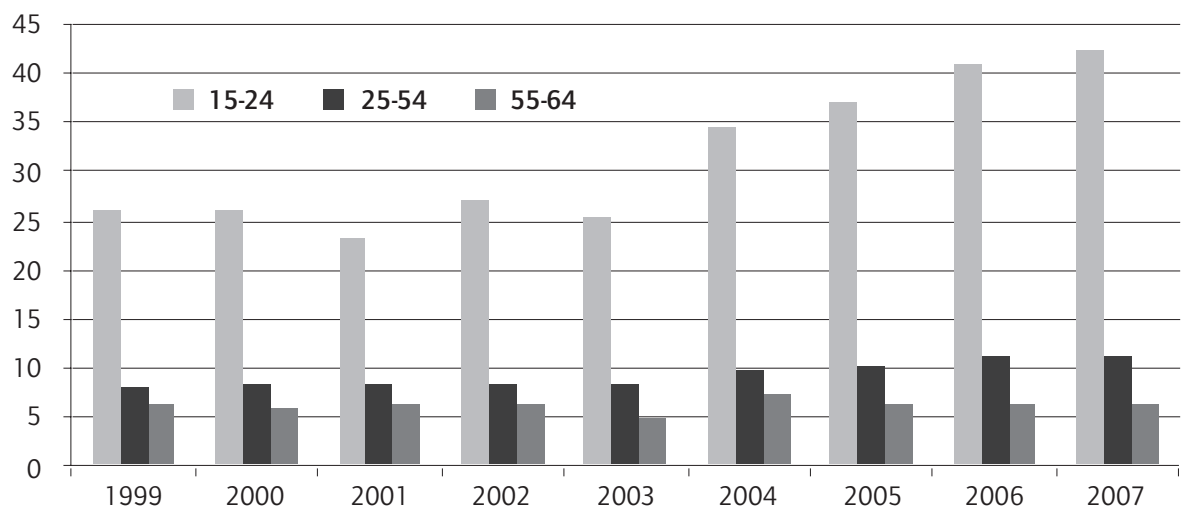

Source: Eurostat (Ifsta_etpgan)

These atypical jobs are associated with lower employment protection and no or limited access to unemployment benefits and the wage guarantee system (Cassa Integrazione Guadagni) that guarantees workers on permanent contract a subsidised replacement wage equal to $80 \%$ of their in-work wage (Aricò and Stein 2012: 287). The growth of such jobs has thus been cited as evidence that the Italian Labour market has become highly dualised (Garibaldi and Taddei 2013) which, it could be argued, was precisely the intention, namely, to create a less secure employment framework to stimulate creation of less secure jobs and/or to convert extremely insecure informal jobs into insecure formal jobs. In fact, legal segmentation of the labour market existed in other forms too. As pointed out by Jessoula et al. (2010: 562), an insider/outsider-based dichotomy ${ }^{4}$ ignores another essential distinction, namely that between permanent workers in firms with less than 15 employees and those working in firms employing 15 or more. Permanent workers in the former category have less employment protection - Article 18 does not apply to firms of this size - although they are as likely as those in larger firms to meet the contributory requirements for unemployment benefits and pensions.

The insider-outsider dichotomy additionally fails to take account of the considerable differences between the different types of non-standard contractual arrangements. For example, social contributions for workers on fixed-term or part-time contracts are the same as for those on permanent contracts, whereas workers on project contracts (co.co.pro and co.co.co) are subject to lower social contributions and therefore also less likely to meet the contributory criteria for pension and unemployment benefits. More importantly, this dichotomy still overlooks the great differences between

4. 'Insiders' are seen by these authors as enjoying the cumulative advantages of relatively high job protection and high benefits when unemployed: these are employees in the public sector and in medium-to-large unionised firms. 'Outsiders' suffer from the cumulative disadvantages of exclusion from regular employment and the absence of any reliable form of income protection. 
workers in the sizeable shadow economy and those in regularised employment (Jessoula et al. 2010: 567).

Segmentation of the Italian labour market is thus more complex than is suggested by the simple dichotomy used to justify reductions in protection for workers on permanent contracts. Indeed, the rich body of theory on labour market segmentation has emphasised themes such as labour market disadvantage and discrimination that lead some individuals and groups into less secure and worse paid employment. A reduction of formal protection for more secure employees would appear to be of very little relevance in any effort to overcome other powerful roots of labour market segmentation such as these. 


\section{The Italian labour market during the crisis}

The Italian economy passed through distinct phases after 2008, as shown in Table 3: in 2008-2011, the unemployment level did not substantially differ from the EU28 average; during the second period, 2011-2013, it began to increase more rapidly, reaching $12.7 \%$ in 2014 - the second highest proportional increase in the Eurozone in this period (Eurostat 2015).

Table 3 Unemployment rate 2008-2013

\begin{tabular}{|l|r|r|r|r|r|r|c|}
\hline Unemployment rate (15+) & \multicolumn{9}{|c|}{} & \multicolumn{2}{|c|}{ Change \% } \\
\cline { 2 - 8 } & $\mathbf{2 0 0 8}$ & $\mathbf{2 0 0 9}$ & $\mathbf{2 0 1 0}$ & $\mathbf{2 0 1 1}$ & $\mathbf{2 0 1 2}$ & $\mathbf{2 0 1 3}$ & $\mathbf{2 0 0 8 - 2 0 1 3}$ \\
\hline Greece & 7.8 & 9.6 & 12.7 & 17.9 & 24.5 & 27.5 & $252.6 \%$ \\
\hline Spain & 11.3 & 17.9 & 19.9 & 21.4 & 24.8 & 26.1 & $131.0 \%$ \\
\hline Ireland & 6.4 & 12.0 & 13.9 & 14.7 & 14.7 & 13.1 & $104.7 \%$ \\
\hline Italy & 6.7 & 7.8 & 8.4 & 8.4 & 10.7 & 12.2 & $82.1 \%$ \\
\hline European Union (28 countries) & 7.0 & 8.9 & 9.6 & 9.6 & 10.5 & 10.8 & $54.3 \%$ \\
\hline United Kingdom & 5.6 & 7.5 & 7.8 & 8.1 & 7.9 & 7.6 & $35.7 \%$ \\
\hline Germany & 7.4 & 7.6 & 7.0 & 5.8 & 5.4 & 5.2 & $-29.7 \%$ \\
\hline
\end{tabular}

Source Eurostat (Ifsa_ergan) own calculations

Comparison of the trends in unemployment with GDP changes, as in Figure 3, shows trends similar to those of the EU as a whole. GDP fell most steeply in 2009, having already started its decline in 2008, while the increase in unemployment was less dramatic, implying declining labour productivity. The contraction in GDP in Italy was more pronounced than the EU28 average and had already started in 2008. GDP growth in 2010 and 2011 was much slower than the EU28 average and the GDP contraction in 2012 and 2013 was greater. Unemployment began to increase more rapidly with the renewed fall in GDP.

Unemployment figures should be read alongside the employment figures as the former can be influenced both by changes in numbers of discouraged workers and by migration. Italy already had one of the lowest rates of employment in the EU and it decreased still further, albeit not as rapidly as in other economies hard hit by the economic downturn, notably Spain, Ireland and Greece (Table 4). The number of people leaving the country increased from 51,113 in 2007 to 125,735 in 2013 , but this had a negligible impact on the employment rate (ISTAT 2015b). 
Figure 3 Unemployment and real GDP growth rate $(2007=0)$

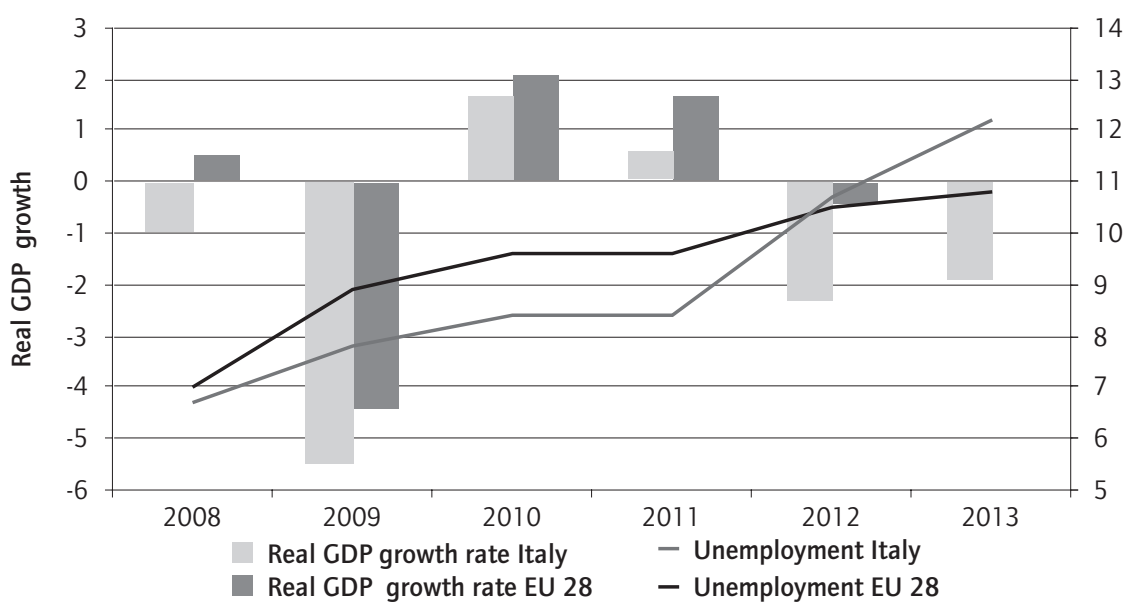

Source: Eurostat (une_rt_a, tec00115), own calculations

Table 4 Employment rate for selected countries, 15+

\begin{tabular}{|l|r|r|r|r|r|r|c|}
\hline Unemployment rate (15+) & \multicolumn{7}{|c|}{ Change \% } \\
\cline { 2 - 9 } GE0/TIME & $\mathbf{2 0 0 8}$ & $\mathbf{2 0 0 9}$ & $\mathbf{2 0 1 0}$ & $\mathbf{2 0 1 1}$ & $\mathbf{2 0 1 2}$ & $\mathbf{2 0 1 3}$ & $\mathbf{2 0 0 8 - 2 0 1 3}$ \\
\hline Greece & 61.4 & 60.8 & 59.1 & 55.1 & 50.8 & 48.8 & $-20.5 \%$ \\
\hline Spain & 64.5 & 60.0 & 58.8 & 58.0 & 55.8 & 54.8 & $-15.0 \%$ \\
\hline Ireland & 67.6 & 61.9 & 59.6 & 58.9 & 58.8 & 60.5 & $-10.5 \%$ \\
\hline Italy & 58.7 & 57.5 & 56.9 & 56.9 & 56.8 & 55.6 & $-5.3 \%$ \\
\hline European Union (28 countries) & 65.7 & 64.5 & 64.0 & 64.2 & 64.1 & 64.1 & $-2.4 \%$ \\
\hline United Kingdom & 71.5 & 69.9 & 69.5 & 69.5 & 70.1 & 70.8 & $-1.0 \%$ \\
\hline Germany & 70.1 & 70.3 & 71.1 & 72.5 & 72.8 & 73.3 & $4.6 \%$ \\
\hline
\end{tabular}

Source: Eurostat, own calculations

Thus the changes in employment are broadly captured in the figures for the changes in unemployment. As Table 4 shows, in Italy the employment rate showed a significant fall of $5.3 \%$, while GDP fell by $7.7 \%$. Figures for the EU28 were $2.4 \%$ and $1.4 \%$ respectively, suggesting a degree of numerical flexibility in the Italian labour market possibly greater than for the EU as a whole. Figure 4 shows this comparison, with trends comparable to those in Figure 3.

When broken down in more detail, these employment changes show some small differences as compared with other EU member states. As elsewhere, impacts differed depending on contractual arrangements. Those on temporary contracts were the most affected by the crisis. In fact, in the first years of the crisis, job losses were concentrated among workers on fixed-term $(-16.2 \%)$ and project contracts $(-15.9 \%)$ rather than among those on permanent contracts (-0.7\%) (Anelli and Basso 2012). However, there was also a surprising increase in the numbers employed in part-time work, mostly due to a growth in the involuntary part-time category, as shown in Figure 5. 
Figure 4 Real GDP growth and employment rate $(2007=0)$

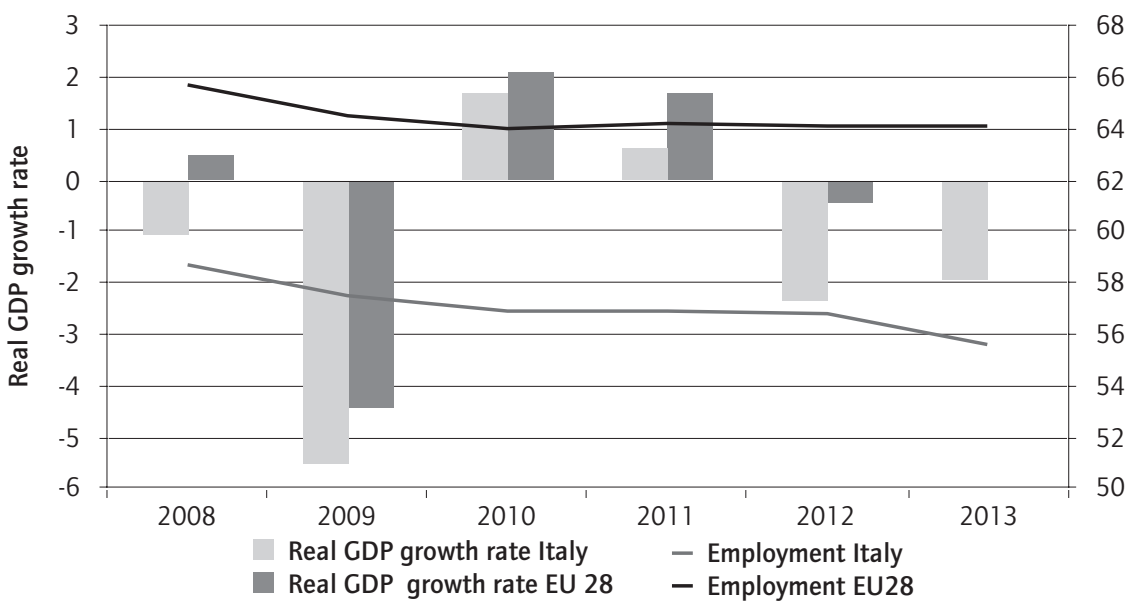

Source: Eurostat (Ifsi_emp_a, tec00115), own calculations

Figure 5 Part-time and involuntary part-time workers

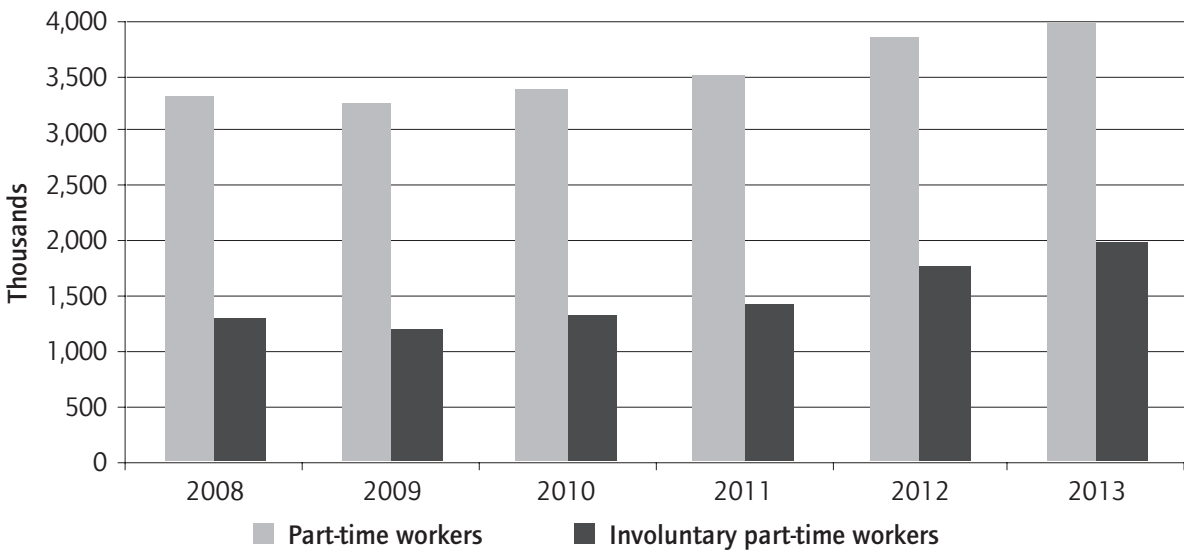

Source: Istat, Eurostat (Ifsan_epgan2), own calculations

The sectoral impact of the crisis, shown in Table 5, also broadly followed EU trends. The biggest contractions took place in construction and manufacturing, in line with labour market developments in other countries (see Myant and Piasna 2014). However, and unlike the picture in many northern European countries, this was accompanied by a negative performance in education, in professional, scientific and technical activities, and in information and communication services, with a sharp decrease in the number of full-timers and a substantial increase in the number of part-timers in the last two of these categories. Structural changes were taking Italy further away from a knowledgebased economy.

However, three specificities of the Italian labour market find analogies in, at most, only some other EU member states. These are the regional divergences, the wage guarantee fund which was used to maintain employment levels, and 
Table 5 Changes in employment (in '000s), by working time and selected sectors, age 15-64

\begin{tabular}{|c|c|c|c|c|c|c|}
\hline & Total employment & & ployme & Chan & e 2008-20 & 12 \\
\hline & 2008 & 2012 & All $\%$ & All & Full-time & Part-time \\
\hline Manufacturing $(\mathrm{C})$ & 4,665 & 4,208 & -10 & -458 & -458 & 1 \\
\hline Construction (F) & 1,987 & 1,754 & -12 & -233 & -242 & 9 \\
\hline Retail (C) & 3,503 & 3,377 & -4 & -126 & -199 & 73 \\
\hline Public administration (0) & 1,312 & 1,371 & 5 & 60 & 107 & -48 \\
\hline $\begin{array}{l}\text { Professional, scientific and } \\
\text { technical (M) }\end{array}$ & 1,458 & 1,355 & -7 & -103 & -123 & 20 \\
\hline Information and communication ( $\mathrm{J}$ ) & 655 & 643 & -2 & -12 & -30 & 19 \\
\hline Education (P) & 1,754 & 1,691 & -4 & -62 & 52 & -114 \\
\hline $\begin{array}{l}\text { Other services of business economy } \\
(H, I, K, L, N, S)\end{array}$ & 4,641 & 4,729 & 2 & 88 & -122 & 209 \\
\hline Health (Q) & 1,643 & 1,780 & 8 & 138 & 86 & 52 \\
\hline $\begin{array}{l}\text { Activities of households as } \\
\text { employers (T) }\end{array}$ & 420 & 728 & 74 & 308 & 139 & 170 \\
\hline
\end{tabular}

Source: Eurostat (Ifsa_epgan2), own calculations

the importance of household employment. These three features are discussed in turn below.

It is impossible to examine the Italian economy without taking into consideration the socio-economic disparities between North and South (Bagnasco 1977; O'Higgins 2011: 314). As shown in Figure 6, whereas the Mezzogiorno had one of the highest unemployment rates before the crisis (11\% in 2007), Northern Italy had one of the lowest (3.5\% in 2007). Although the unemployment increases in Southern Italy have been high by any standards, reaching $20.7 \%$ in 2014, the unemployment rate in the North also more than doubled as it rose to $8.6 \%$ in 2014 .

The disparity between North and South is even starker when we look at employment levels. Whereas the rate for the North (64.9\% in 2012) is almost in line with the rest of Europe (64\% in 2012), the Mezzogiorno has one of the very lowest rates (43.7 \% in 2012). Employment figures for Italy would be considerably higher if its sizeable shadow economy were included ${ }^{5}$, accounting in 2008 for between $17.5 \%$ and $26.3 \%$ of GDP, depending on the methodology used to measure it (ISTAT 2010; Schneider and Torrini 2012). In 2008, before the crisis, ISTAT estimated that $11.9 \%$ of the total number of people employed worked in irregular employment ${ }^{6}$ (ISTAT 2010). In the Mezzogiorno in 2008 $18.3 \%$ of the population in employment worked in the shadow economy as against 8.9\% in the North East (MEF 2011).

5. Istat defines shadow economy (economia sommersa) as the income deriving from the production of legal goods and services that are concealed from public authorities to avoid tax, regulatory and administrative regulations.

6. According to the methodology used by ISTAT, the percentage of total employment working in the shadow economy reached $12.3 \%$ in 2009, starting its upward trend regardless of regional disparities (MEF 2011). 


\section{Figure 6 Unemployment rate by geographical area}

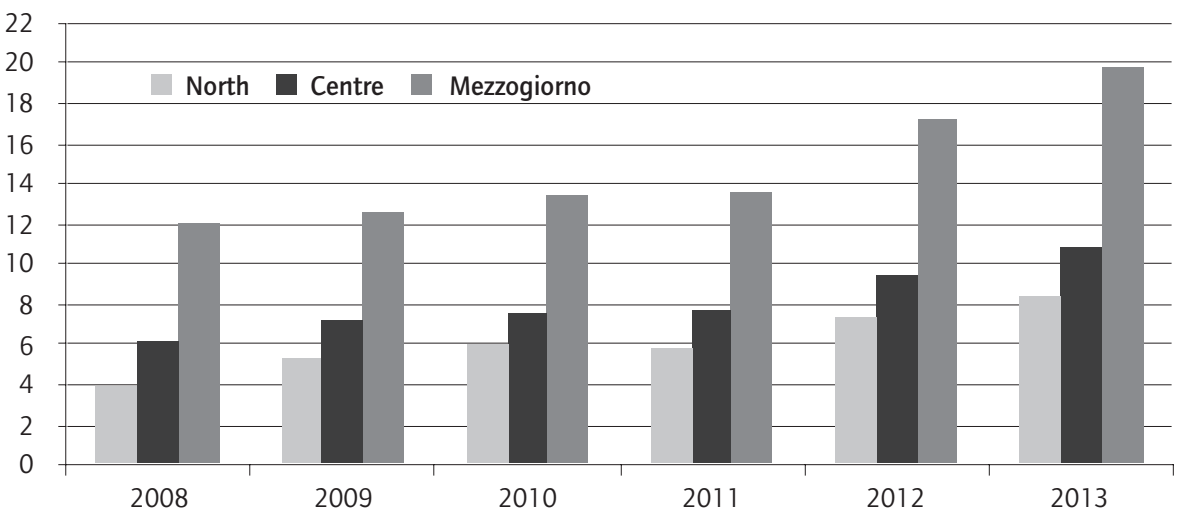

Note: North (Piemonte, Valle d'Aosta, Lombardia, Liguria, Trentino-Alto Adige/Sudtirol, Veneto, Friuli-Venezia Giulia, Emilia Romagna), Centre (Toscana, Umbria, Marche, Lazio), Mezzogiorno (Abruzzo, Molise, Campania, Puglia, Basilicata, Calabria, Sicilia, Sardegna).

Source: Eurostat (Ifst_r_lfu3rt)

Part of the reason why Southern Italy was harder hit by the crisis stems from the production distribution, namely the high concentration of industry in the North, and the way in which the Wage Funded system, discussed below, was set up to apply to industrial workers in firms with a minimum of 15 employees (O'Higgins 2011: 327).

Following the sector breakdown by geographical area, shown in Table 6, the largest proportional changes in the sectors most affected by the crisis took place in the Mezzogiorno where Industry and Construction contracted by $14 \%$ and $32 \%$ respectively. Southern Italy was also more affected by the cuts in the public sector $^{7}(-9 \%)$ than were the North and Centre where employment remained stable.

More generally, these regional disparities in both the starting levels and the changes resulting from the crisis show that high unemployment in the South cannot be the result of labour market legislation which is the same throughout Italy.

The impact of the crisis on unemployment in the first period was cushioned by the Wage Funded system - Cassa integrazione guadagni (CIG) (Aricò and Stein 2012: 276; Hijzen and Venn 2011: 6) following a government decision in 2009 to extend the eligibility criteria to a wider category of workers (Aricò and Stein 2012: 288), including those on fixed-term contracts, apprenticeships and project contracts (co.co.pro and co.co.co) - although the period for which they received this subsidised wage could not extend beyond the duration of the contract. The impact of this programme on average hours worked is shown in Figure 7: in Italy the decline was more rapid than the EU average.

7. The number of public sector jobs in Southern Italy sharply increased in the $1980 \mathrm{os}$. In the period 1970-1989, employment in the Mezzogiorno increased by 935,000; of these 601,000 were in the public sector (Bodo and Viesti 1998: 13) 
Table 6 Employment by selected sectors (in '000s)

\begin{tabular}{|l|r|r|r|r|}
\hline Industry & $\mathbf{2 0 0 8}$ & $\mathbf{2 0 1 3}$ & Change & \% Change \\
\hline North & $3,186.7$ & $2,955.9$ & -230.8 & $-7 \%$ \\
\hline Centre & 909 & 785.3 & -123.7 & $-14 \%$ \\
\hline Mezzogiorno & 904.8 & 777.8 & -127 & $-14 \%$ \\
\hline Construction & $\mathbf{2 0 0 8}$ & $\mathbf{2 0 1 3}$ & Change & $\%$ Change \\
\hline North & 959.4 & 808.4 & -151 & $-16 \%$ \\
\hline Centre & 385.1 & 345.7 & -39.4 & $-10 \%$ \\
\hline Mezzogiorno & 642.4 & 437.3 & -205.1 & $-32 \%$ \\
\hline Public administration, defence, education, & 2008 & 2013 & Change & $\%$ Change \\
\hline human health and social work activities & & & & $1 \%$ \\
\hline North & $2,047.3$ & $2,070.0$ & 22.7 & $-1 \%$ \\
\hline Centre & $1,006.0$ & 995.1 & -10.9 & $-9 \%$ \\
\hline Mezzogiorno & $1,635.0$ & $1,485.3$ & -149.7 & $1 \%$ \\
\hline
\end{tabular}

Source: Eurostat, [lfst_r_lfe2en2], own calculations

Figure 7 Average number of usual weekly hours for employed persons

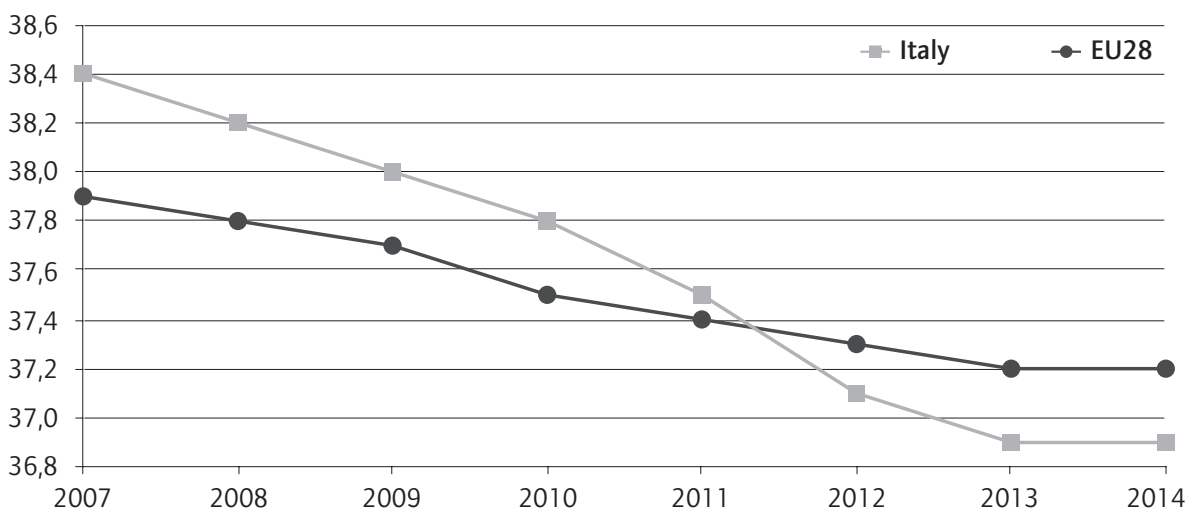

Source: Eurostat (Ifsa_ewhuis), own calculations

After reaching a peak in 2010, the number of hours covered by the programme remained high, albeit with some fluctuations. This mainly involved workers in industry $-62 \%$ of the total in 2012 - the sector for which it was originally set up.

The impact on the official unemployment rate is considerable since even those in the scheme who are working zero hours - in 2012, 522,344 workers - are included among the employed in the statistics (O'Higgins 2011: 327). Had these zero-hour workers been classified as unemployed, the unemployment rate would have been 2 percentage points higher in those years, as shown in Figure 9.

A peculiar feature of the Italian labour market is the growth in the category classified as 'activities of households as employers', shown in Table 5. This includes employment of paid domestic staff directly by households, as well as production for own consumption where no formal transaction needs to take 
Figure 8 Number of workers on $\mathrm{CIG}$

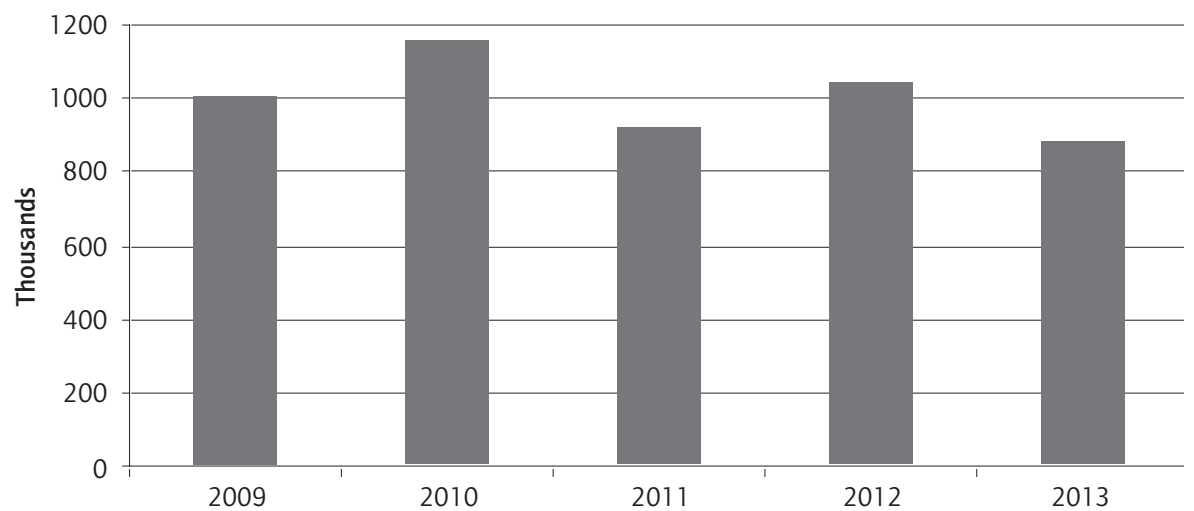

Source: $\mathrm{CIGL}$, Osservatorio $\mathrm{CIG}$

Figure 9 Unemployment rate including employees on $\mathrm{CIG}$ on zero hours

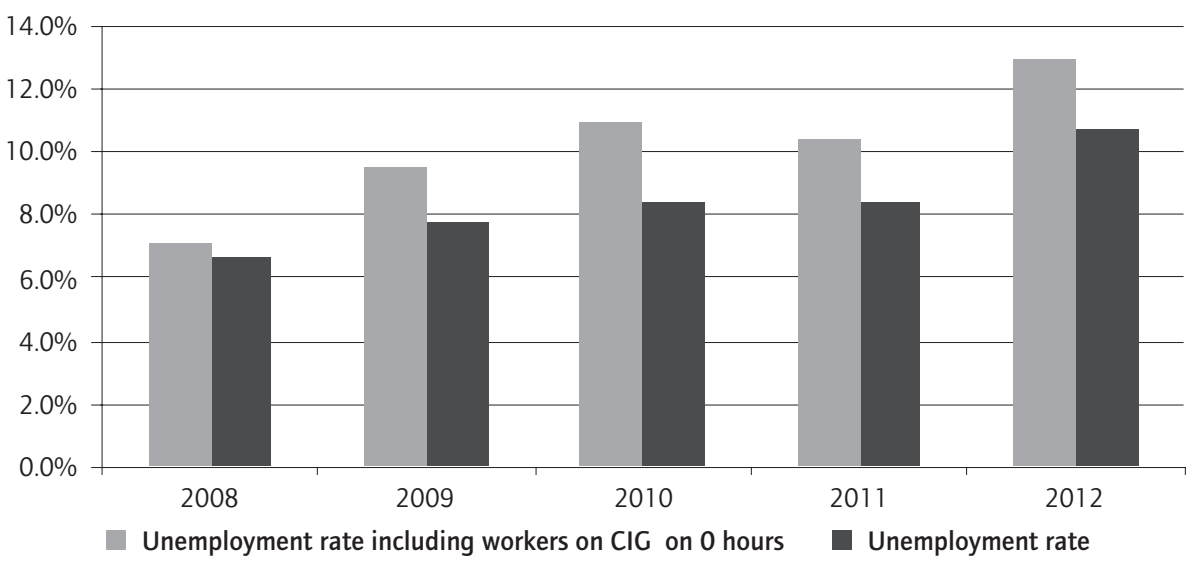

Note: CIG Ordinaria, Straordinaria and in Deroga have been added together

Source: CIGL, Rapporto CIG 2014, Eurostat (une_rt_a) own calculations

place. The first of these two sub-categories would seem to account for this increase.

This phenomenon has been interpreted as a response to the inadequacy of the welfare state in addressing demographic changes and new social risks (van Hooren 2012). Considering that, in 2015, 21.6\% of the population were over 65 , this expansion could be seen as a way to satisfy the demand for elderly care (ISTAT 2015a). However, it is not clear whether this increase corresponds to the creation of genuinely new jobs or represents a transition from irregular to regular work. In this period, the government incentivised the regularisation of illegal immigrants in employment and $80 \%$ of the new jobs created in this sector were taken by migrants. The number of registered foreign domestic workers increased from 530,000 to 800,000 between 2008 and 2009 at the time of a second amnesty (Da Roit et al. 2013: 587). 


\section{Article 18 and the Fornero Reform}

In this section, we will discuss the reforms introduced since 2011 with a particular focus on the controversy behind Article 18 of the Workers' Statute.

As demonstrated in Section 2, during the first period of the crisis (2008-2011), Italy relied on existing policies to mitigate the impact of the downturn on its labour market. However, in 2011, the rise in interest rates on government bonds, low growth and high public debt led to calls for structural interventions. In August 2011, Jean-Claude Trichet and Mario Draghi, the incumbent and newly elected ECB presidents respectively, sent a letter to the Italian government outlining the structural reforms and spending cuts expected of Silvio Berlusconi's government. Among other requests, they asked the Italian government 'to further reform the collective wage bargaining system allowing firm-level agreements to tailor wages and working conditions to firms' specific needs and increasing their relevance with respect to other layers of negotiations'. They also asked the government to conduct 'a thorough review of the rules regulating the hiring and dismissal of employees in conjunction with the establishment of an unemployment insurance system and a set of active labour market policies capable of easing the reallocation of resources towards the more competitive firms and sectors' (Trichet and Draghi 2011).

Sacchi (2015: 80) argues that these recommendations had some degree of implicit conditionality as they could provoke harsh tacit sanctions: in return for implementing structural reforms, the ECB was committed, albeit not formally, to buying national bonds to alleviate the debt crisis and to avoid the need for any explicit lending programmes with the IMF to prevent a default. Then, in September, a month after the letter was sent, the Italian Parliament approved an emergency austerity budget (Decree-Law 148/2011) that included in its Article 8 an important reform of industrial relations that allowed the 'possibility to derogate, by a company agreement (proximity agreements), from conventional and statutory provisions, including those governing layoffs'. This meant that company agreements could diverge not only from sectoral and national collective agreements but also from National Law and therefore also from the Workers' Statute (Clauwaert and Schömann 2013: 1).

This was billed as a basis upon which to increase employment, improve the quality of employment contracts, put a stop to illegal labour, increase competitiveness and pay, manage industrial and employment crises, and encourage new investments and the start of new activities' (Clauwaert and Schömann 2013: 1). These company agreements could involve 'all aspects of labour organisation and production', including 'recruitment modalities and the 
regulation of the working relationship', as well as the consequences of the termination of the employment relationship, except for discriminatory layoffs' (Clauwaert and Schömann 2013: 1). Hence, as long as they remained in line with the Italian constitution, EU norms and international requirements, these company-level agreements allowed opt-outs on several issues including fixedterm and part-time contracts, temporary agency work, workers' tasks and job classification, hiring procedures, freelance work, transformation and conversion of employment contracts; and firing procedures ${ }^{8}$ (Clauwaert and Schömann 2013: 1). This represented a significant decentralisation of collective bargaining but did not give employers unilateral power to change working conditions without the agreement of trade union representatives at the company level. As a result, changes were small, although court rulings (see Venice Court sentence 583 24/07/2013) could legitimise the use of this kind of agreement in the future (Picot and Tassinari 2014).

The second ECB recommendation referred to Article 18 of the Workers' Statute that applies to firms with 15 employees or more. ${ }^{9}$ This article was considered to represent an obstacle to job creation and to be the main reason why employers would prefer atypical contracts ${ }^{10}$. According to this - prior to the Fornero Reform - a worker found by a judge's ruling to have been unfairly dismissed was entitled to full reinstatement and back-pay. A worker could, alternatively, opt for 15 months of salary by way of compensation (Tompson 2009: 252). Firms employing less than 15 workers were required to pay monetary compensation alone (Garibaldi and Taddei 2013: 27).

In October 2011, Berlusconi's government committed itself to carrying out extensive reforms by the end of the year including 'a reform of labour legislation promoting greater readiness to take on employees and the efficiency requirements of business by means of, among other things, new rules governing dismissals for economic reasons in permanent employment contracts' (http://blogs.ft.com/brusselsblog/files/2011/11/BerlusconiLetter.pdf). However, in November 2011, as Italy was under pressure from international financial markets, Berlusconi resigned to restore trust in the country's ability to deal with its high debt (Picot and Tassinari 2014).

In spite of the fact that Italy, prior to the reform, was identified as the country with the highest dismissal costs in Europe, evaluating the impact of Article 18

8. These had to comply with existing legislation on discriminatory dismissals.

9. The 15 employees refer to the date on which the firing was intimated, which can be ahead of the actual separation date. Further, apprentices and temporary workers on contracts lasting less than nine months should not be computed. However, part-time workers should be included in proportion to their working hours, and all other temporary contracts should be counted. Finally, any form of employment that does not classify as dependent employment (interim workers, full-time and part-time consultants) should not be included in the labourcode-based definition of employment. Article 18 applies to agricultural firms employing more than 5 employees.

10. There are no differences in terms of social contributions between permanent contracts (fulltime and part-time) and fixed-term contracts (full-time and part-time), which might otherwise explain such a preference. 
on the labour market is no straightforward task (Deloitte 2012). One reason for this is that there are no official statistics on the number of workers reinstated (Sciotto 2014). This is because most litigation is settled out-of-court and limited to pecuniary compensation rather than reinstatement. Despite the lack of evidence on the procedural costs of Article 18, the study conducted by Ichino and Pinotti (2012) indicated substantial variations between cities in average duration of trials for unfair dismissals, adding a degree of uncertainty to business operations.

Since it applies only to firms with 15 or more employees, Article 18 is considered to have a detrimental effect on the scaling-up process and consequently on the creation of new jobs, even though it is not the only regulation that applies above this threshold ${ }^{11}$ (Schivardi and Torrini 2004; Zingales and Pellegrino 2014). According to this line of reasoning, firms will not grow beyond the threshold to avoid stricter regulations (Bentolila and Bertola 1990). If this were true, we would expect a concentration of firms below the 15-employee threshold. However, the study conducted by Tattara (1999) showed no threshold effects on the size distribution of companies. Other studies conducted by Garibaldi et al. (2004) and by Schivardi and Torrini $(2004)^{12}$ found the 15 -employee threshold to have a statistically significant, but quantitatively very small, impact on the size of firms ${ }^{13}$. The studies also found no significant distribution discontinuity between firms with 15 and 16 employees. A possible explanation for the lack of importance of the thresholds is that companies around the 15-employees size can use more flexible contractual arrangements or employ other workers illegally to circumvent the restrictions on dismissal outlined in Article 18 (Garibaldi et al. 2004; Schivardi and Torrini 2004).

Despite pressure from employers to amend Article 18, the situation had remained unchanged for a long time. The second Berlusconi government attempted to relax the dismissal regulations by introducing financial compensation without reinstatement (Chiesi 2013; Garibaldi and Taddei

11. Other regulations apply to this threshold. Firms employing 15 and more workers must employ disabled workers. Further rules of the labour code linked to union-related activity apply only to firms employing 15 and more employees. The threshold of 15 workers is also relevant for the establishment of the 'Rappresentanze Sindacali Aziendali'. Workers in firms with more than 15 employees can elect trade union representatives at firm level, who can call general meetings, affix posters on union activities, and call referendums. Collective dismissal procedures are in place above the 15 employees threshold. Firms employing more than 10 workers are obliged to hire disadvantaged workers, meaning the officially registered long-term unemployed.

12. Schivardi and Torrini (2004) acknowledge the threshold effect of trade union activity. However, they claim the practical relevance of this threshold to be minor as 'trade union membership and activity within the firm do not depend on the presence of a 'Rappresentanza Sindacale Aziendale'. Moreover, collective agreements apply also to workers and firms that do not belong to unions and employer organisations'.

13. The threshold effect reduces the probability of growing by approximately 2 percentage points for firms with 13-15 employees. The share of firms above the 15 threshold increases by small amounts, always below $1 \%$. These are clearly small effects, in particular in the light of the 'Italian anomaly' according to which firm size in Italy is substantially lower than the EU average (3.9 versus 6.1). 
2013). The same idea was included in Biagi's proposal but failed to become law because of opposition by trade unions and mobilisation of millions of workers (Tompson 2009: 256).

Not until 2012, in the midst of the Euro debt crisis and under pressure from the ECB, did Mario Monti's technocratic government succeed in changing Article 18. These changes were included in the 'Fornero Reform', a large piece of legislation consisting of 270 paragraphs grouped into 4 articles to facilitate the approval process (Watanabe 2015). This was presented as one of the most important reforms of the then government and it was claimed that it would radically change the Italian labour market by introducing 'good' flexibility, by increasing exit flexibility and making the unemployment benefits more inclusive, succeeding where previous governments had failed (Tiraboschi 2012: 50 ). With regard to exit flexibility, the government intended to introduce more flexibility in hiring through open-ended contracts by making dismissals easier, a change that would, supposedly, scale back the use of atypical contracts and reduce labour market dualisation (Picot and Tassinari 2014).

The reform dealt with three important dimensions of the Italian labour market: unemployment benefits; atypical contracts; and dismissal regulations for regular contracts (Tiraboschi 2012; Watanabe 2015).

In the name of 'good flexibility', the ordinary unemployment insurance was replaced by a new instrument, the ASPI (Assicurazione Sociale per l'Impiego - Social Insurance for Employment). ASPI benefits were marginally higher than under the previous system; the duration was increased so as to reach 12 months by 2016; employees on apprenticeship contracts were fully enrolled in the new scheme. Another new instrument, the Mini-ASPI, was established to cover those workers who did not fully meet the contributory requirements. In March 2015, ASPI and Mini-Aspi were replaced by the NASPI (Nuova prestazione di Assicurazione Sociale per l'Impiego). According to Sacchi (2013), this newly implemented system reduced by two thirds the number of workers not covered, benefiting in particular workers on fixed-term contracts and temporary agency workers. Whereas the level of benefits for ASPI and Mini-ASPI are the same, the duration of Mini-ASPI is shorter. Moreover, as workers in atypical employment are more likely to have gaps in employment, this unemployment benefits system arguably does little to eliminate the gap between employees in standard and those in non-standard employment.

Additionally, the reform attempted to discourage the use of fixed-term contracts by increasing the 'cooling-off' period between two consecutive contracts $^{14}$ (Garibaldi and Taddei 2013: 24). However, whilst the reform regulated and disincentivised temporary contracts, it also did away with the need to provide a reason for a first fixed-term contract lasting up to one year (Bano 2012). At the same time, it introduced new regulations to curb the rise

14. For contracts of up to 6 months the cooling-off period was increased from 10 to 60 days. For contracts lasting longer than 6 months the cooling-off period was increased from 20 to 90 days. If the cooling-off period is not respected, the contract will be considered permanent. 
of project work and self-employment, by making the definition of 'project' more stringent, by establishing a minimum wage directly linked to collective agreements, and by increasing the required level of social contributions. Accordingly, the reform did somewhat improve, from a legal perspective, the conditions of atypical workers. De facto differences remain, nonetheless, between standard and non-standard employment as employees on irregular contracts are less likely to meet the contributory requirements for pensions and unemployment benefits.

With regard to regular permanent contracts, and more specifically to Article 18, the Fornero Reform reduced the likelihood of an automatic reinstatement and gave the judge, instead of the employee, the power to choose between reinstatement and monetary compensation ${ }^{15}$ (Picot and Tassinari 2014). For those employed after the implementation of the Jobs Act in March 2015 and unlawfully dismissed for economic reasons, reinstatement is no longer an option; for the newly employed (after March 2015) the compensation depends on the years of employment. The reformed Article 18 awards to the employees unlawfully dismissed monetary sanctions equal to 12 to 24 times monthly pay. The right of reinstatement still applies to dismissal for discriminatory reasons even after the Jobs Act.

From an institutional perspective, the Fornero reform somewhat changes the direction of labour market policy in Italy. Whereas previous attempts focused on injecting flexibility at the margins, the Fornero reform was said to redress the employment protection asymmetry between workers on atypical contracts and those on permanent ones. With changes to Article 18, it was the first time that employment protection had been reduced for employees on permanent contracts.

Figure 10 Strictness of employment protection for selected countries (individual dismissals) - regular contracts

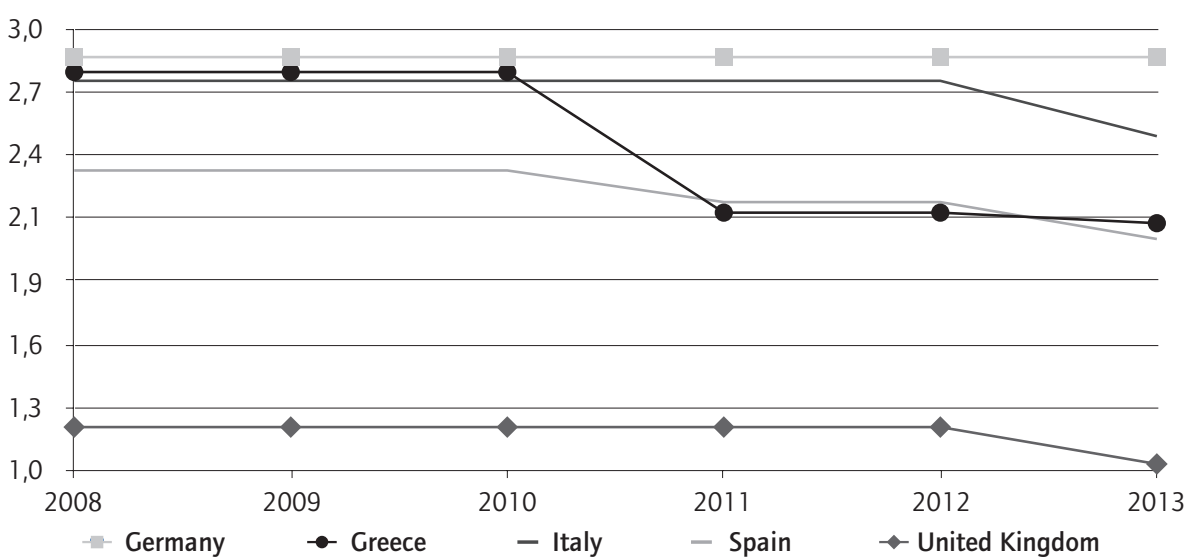

Source: OECD, own calculations

15. In case of dismissal for objective economic reasons, the court can enforce the reinstatement if the economic reason was 'manifestly non-existent'. 
When compared to other countries, employment protection for individual dismissals on regular contracts is still much higher than in liberal economies such as the UK, and substantially higher than in Spain or Greece, yet considerably lower than in Germany, as shown in Figure 10. What is more, there remain important differences between workers on permanent contracts and those on atypical contracts. For example, workers on temporary contracts with gaps in their working lives have limited access to unemployment benefits. Project workers remain excluded from the wage-funded system and are less likely to meet the contributory requirements for pensions and unemployment benefits. 


\section{Evaluation of the Fornero Reform}

This section follows the impact of the Fornero Reform on the Italian labour market. The unemployment rate by geographical region for the period 20112014 (Q3) shows no major change in the North in the wake of implementation of the reform: it continued its upward trend. In the Centre and the Mezzogiorno it has increased even more, as shown in Table 7.

Table 7 Unemployment rate by geographical groups, 2011-2014

\begin{tabular}{|c|c|c|c|c|}
\hline & & North & Centre & Mezzogiorno \\
\hline \multirow{4}{*}{2011} & Q1 & 6.00 & 7.50 & 14.06 \\
\hline & Q2 & 5.22 & 6.60 & 13.09 \\
\hline & Q3 & 5.15 & 7.25 & 12.35 \\
\hline & Q4 & 6.72 & 9.19 & 14.85 \\
\hline \multirow[t]{4}{*}{2012} & Q1 & 7.60 & 9.55 & 17.72 \\
\hline & Q2 & 7.34 & 8.90 & 17.06 \\
\hline & Q3 & 6.85 & 8.78 & 15.52 \\
\hline & Q4 & 7.95 & 10.84 & 18.33 \\
\hline \multirow[t]{4}{*}{2013} & Q1 & 9.16 & 11.28 & 20.07 \\
\hline & Q2 & 8.11 & 10.80 & 19.79 \\
\hline & Q3 & 7.59 & 10.19 & 18.54 \\
\hline & Q4 & 8.87 & 11.16 & 20.49 \\
\hline \multirow[t]{3}{*}{2014} & Q1 & 9.49 & 12.27 & 21.71 \\
\hline & Q2 & 8.39 & 10.78 & 20.29 \\
\hline & Q3 & 7.78 & 10.72 & 19.61 \\
\hline
\end{tabular}

Source: Istat, own calculations

The employment rate in the North and Mezzogiorno, as shown in Table 8, continued its downward trend after the reform, whereas it fluctuated in the Centre. The employment rate in the Mezzogiorno, much lower than the other regional groups, fluctuated until 2012 before decreasing more sharply. This observation supports the argument that the labour market in Southern Italy follows dynamics of its own and different from those observed in the rest of the country.

Overall, there is no evidence of a positive impact resulting from the reforms. However, these aggregate figures cannot be considered conclusive evidence over so short a period and with so many other possible influences. A better guide is provided by a focus on the employment structure, examining the 
effects of the Fornero reform in terms of its immediate aims, namely reducing the incidence of atypical employment and increasing the incidence of regular contracts.

Table 8 Employment rate by area, 2011- 2014

\begin{tabular}{|c|c|c|c|c|}
\hline & & North & Centre & Mezzogiorno \\
\hline \multirow[t]{4}{*}{2011} & Q1 & 65.2 & 61 & 43.4 \\
\hline & Q2 & 65.1 & 61.8 & 44.3 \\
\hline & Q3 & 65 & 60.9 & 44 \\
\hline & Q4 & 65.2 & 60.4 & 43.9 \\
\hline \multirow[t]{4}{*}{2012} & Q1 & 64.9 & 60.7 & 43.2 \\
\hline & Q2 & 65 & 61.8 & 44.2 \\
\hline & Q3 & 65 & 61 & 43.9 \\
\hline & Q4 & 64.7 & 60.7 & 43.6 \\
\hline \multirow[t]{4}{*}{2013} & Q1 & 63.9 & 59.7 & 42.3 \\
\hline & Q2 & 64.2 & 60.4 & 42 \\
\hline & Q3 & 64.3 & 60 & 41.9 \\
\hline & Q4 & 64.2 & 60.9 & 41.8 \\
\hline \multirow[t]{3}{*}{2014} & Q1 & 63.6 & 60.4 & 41.3 \\
\hline & Q2 & 64.5 & 60.9 & 41.7 \\
\hline & Q3 & 64 & 61.1 & 41.9 \\
\hline
\end{tabular}

Source: Istat, own calculations

Table 9 follows the number of jobs created since implementation of the Reform by contractual arrangements, showing not an increase in number of regular contracts but rather a significant contraction. The number of project contracts (co.co.pro) has declined. This could be related to the restrictions imposed on this type of contract by the Fornero reform that took effect in July 2012, and yet the number of project contracts created was decreasing already before implementation of the Reform. The number of fixed-term contracts has been increasing since the Fornero Reform and in the last quarter 2013 this category accounted for $67.8 \%$ of new contracts created, up from $63.7 \%$ in 2012 for the same period. It should be noted that this refers to the number of contracts and, as these may last less than a year, a worker is likely to hold two or more contracts per year: this might partially explain the higher share of temporary contracts. Nevertheless, even if this aspect is taken into consideration, the reform does not seem to have had any impact on the trend. Nor does the reform seem to have had any impact on permanent contracts with the share in the last quarter of 2013 being $16.1 \%$, down from 17.6\% in the last quarter of 2012. Thus there is no evidence of successful incentivisation of their use.

Table 10 shows the numbers of jobs lost by contractual arrangements. The lowering of individual dismissal costs did not correspond to an increase in numbers of jobs lost by workers on permanent contracts. In fact, the number of jobs lost covered by regular contracts has decreased since implementation of the reform. This may suggest either that changes to Article 18 did not go far 
Table 9 Jobs created by contractual arrangements (in '000s)

\begin{tabular}{|c|c|c|c|c|c|c|}
\hline & & Permanent & Temporary & Apprenticeship & Project & Others \\
\hline \multirow[t]{4}{*}{2011} & Q1 & 519.42 & $1,575.75$ & 72.52 & 261.74 & 155.20 \\
\hline & Q2 & 452.88 & $1,810.74$ & 92.04 & 204.57 & 261.84 \\
\hline & Q3 & 456.75 & $1,682.50$ & 71.89 & 202.25 & 211.32 \\
\hline & Q4 & 409.91 & $1,500.97$ & 60.21 & 222.20 & 214.81 \\
\hline \multirow[t]{4}{*}{2012} & Q1 & 515.46 & $1,601.16$ & 77.54 & 272.48 & 240.01 \\
\hline & Q2 & 429.50 & 1738.02 & 80.41 & 196.44 & 333.42 \\
\hline & Q3 & 436.35 & $1,663.87$ & 62.27 & 158.29 & 160.73 \\
\hline & Q4 & 402.88 & 1522.60 & 58.20 & 167.53 & 134.25 \\
\hline \multirow[t]{4}{*}{2013} & Q1 & 453.13 & $1,537.53$ & 59.79 & 200.72 & 136.51 \\
\hline & Q2 & 391.74 & $1,774.97$ & 70.36 & 153.05 & 169.64 \\
\hline & Q3 & 368.77 & $1,690.30$ & 57.90 & 153.01 & 129.96 \\
\hline & Q4 & 364.97 & $1,539.44$ & 54.07 & 167.44 & 140.69 \\
\hline \multirow[t]{2}{*}{ Variation } & $2011 Q 4-2013 Q 4$ & -44.94 & 38.47 & -6.14 & -54.76 & -74.12 \\
\hline & 2012Q4-2013Q4 & -37.91 & 16.84 & -4.13 & -0.09 & 6.44 \\
\hline
\end{tabular}

Share of total jobs created (\%)

\begin{tabular}{|c|c|c|c|c|c|c|}
\hline \multirow[t]{4}{*}{2011} & Q1 & 20.1 & 61.0 & 2.8 & 10.1 & 6.0 \\
\hline & Q2 & 16.0 & 64.2 & 3.3 & 7.2 & 9.3 \\
\hline & Q3 & 17.4 & 64.1 & 2.7 & 7.7 & 8.1 \\
\hline & Q4 & 17.0 & 62.3 & 2.5 & 9.2 & 8.9 \\
\hline \multirow[t]{4}{*}{2012} & Q1 & 19.0 & 59.2 & 2.9 & 10.1 & 8.9 \\
\hline & Q2 & 15.5 & 62.6 & 2.9 & 7.1 & 12.0 \\
\hline & Q3 & 17.6 & 67.1 & 2.5 & 6.4 & 6.5 \\
\hline & Q4 & 17.6 & 66.6 & 2.5 & 7.3 & 5.9 \\
\hline \multirow[t]{4}{*}{2013} & Q1 & 19.0 & 64.4 & 2.5 & 8.4 & 5.7 \\
\hline & Q2 & 15.3 & 69.3 & 2.7 & 6.0 & 6.6 \\
\hline & Q3 & 15.4 & 70.4 & 2.4 & 6.4 & 5.4 \\
\hline & Q4 & 16.1 & 67.9 & 2.4 & 7.4 & 6.2 \\
\hline \multirow[t]{2}{*}{ Variation } & $2011 Q 4-2013 Q 4$ & -0.9 & 5.6 & -0.3 & -1.8 & 2.7 \\
\hline & 2012Q4-2013Q4 & -1.5 & 1.3 & -0.1 & 0.1 & 0.3 \\
\hline
\end{tabular}

Source: Rapport Annuale Sulle Comunicazioni Obbligatorie 2014, Ministero del Lavoro e delle Politiche Sociali, own calculations

enough or, more likely, that Article 18 was not a particularly significant factor in influencing firms' decisions in the period observed. Job losses were concentrated in the category of fixed-term contracts, the numbers of which increased slightly as compared to 2012.

The increase in jobs lost and created on fixed-term contracts may indicate the high turnover associated with this kind of employment contract. However, the number of employees on temporary contracts does not seem to have been affected by the Fornero reform. In fact, if we look at the number of temporary workers as a percentage of total employment, we cannot identify any particular trend. As indicated in Figure 11, levels fluctuated before the Fornero reform and continued to do so afterwards, with the exception of 2014 when they increased more rapidly, reaching $11 \%$ in the third quarter of 2014. 
Table 10 Jobs lost by contractual arrangements (in '000s)

\begin{tabular}{|c|c|c|c|c|c|c|}
\hline & & Permanent & Temporary & Apprenticeship & Project & Others \\
\hline \multirow[t]{4}{*}{2011} & Q1 & 518.291 & 1059.582 & 50.011 & 158.268 & 122.539 \\
\hline & Q2 & 519.232 & 1529.289 & 52.686 & 225.392 & 170.187 \\
\hline & Q3 & 529.005 & 1621.274 & 82.895 & 207.513 & 233.698 \\
\hline & Q4 & 619.838 & 2041.651 & 54.097 & 283.529 & 207.279 \\
\hline \multirow[t]{4}{*}{2012} & Q1 & 518.887 & 1083.039 & 46.317 & 164.486 & 161.884 \\
\hline & Q2 & 504.33 & 1534.927 & 46.406 & 234.557 & 229.322 \\
\hline & Q3 & 518.489 & 1545.274 & 65.94 & 192.296 & 319.972 \\
\hline & Q4 & 648.506 & 2020.209 & 48.79 & 277.265 & 204.062 \\
\hline \multirow[t]{4}{*}{2013} & Q1 & 487.802 & 1070.676 & 42.889 & 144.503 & 130.066 \\
\hline & Q2 & 494.979 & 1519.673 & 42.982 & 195.02 & 165.082 \\
\hline & Q3 & 483.219 & 1530.286 & 52.145 & 163.889 & 157.683 \\
\hline & Q4 & 558.584 & 2104.72 & 44.894 & 219.973 & 180.509 \\
\hline \multirow[t]{2}{*}{ Variation } & $2011 Q 4-2013 Q 4$ & -61.254 & 63.069 & -9.203 & -63.556 & -26.77 \\
\hline & 2012Q4-2013Q4 & -89.922 & 84.511 & -3.896 & -57.292 & -23.553 \\
\hline
\end{tabular}

Share of total jobs lost by contractual arrangements

\begin{tabular}{|c|c|c|c|c|c|c|}
\hline \multirow[t]{4}{*}{2011} & Q1 & 27.2 & 55.5 & 2.6 & 8.3 & 6.4 \\
\hline & Q2 & 20.8 & 61.3 & 2.1 & 9 & 6.8 \\
\hline & Q3 & 19.8 & 60.6 & 3.1 & 7.8 & 8.7 \\
\hline & Q4 & 19.3 & 63.7 & 1.7 & 8.8 & 6.5 \\
\hline \multirow[t]{4}{*}{2012} & Q1 & 26.3 & 54.8 & 2.3 & 8.3 & 8.2 \\
\hline & Q2 & 19.8 & 60.2 & 1.8 & 9.2 & 9 \\
\hline & Q3 & 19.6 & 58.5 & 2.5 & 7.3 & 12.1 \\
\hline & Q4 & 20.3 & 63.2 & 1.5 & 8.7 & 6.4 \\
\hline \multirow[t]{4}{*}{2013} & Q1 & 26 & 57.1 & 2.3 & 7.7 & 6.9 \\
\hline & Q2 & 20.5 & 62.9 & 1.8 & 8.1 & 6.8 \\
\hline & Q3 & 20.2 & 64.1 & 2.2 & 6.9 & 6.6 \\
\hline & Q4 & 18 & 67.7 & 1.4 & 7.1 & 5.8 \\
\hline \multirow[t]{2}{*}{ Variation } & $2011 Q 4-2013 Q 4$ & -1.3 & 4 & -0.3 & -1.7 & -0.7 \\
\hline & 2012Q4-2013Q4 & -2.3 & 4.5 & -0.1 & -1.6 & -0.6 \\
\hline
\end{tabular}

Source: Rapporto Annuale Sulle Comunicazioni Obbligatorie 2014, Ministero del Lavoro e delle Politiche Sociali, own calculations

As shown in Table 11, in the 2012-2013 period, 24\% of formerly unemployed workers entered the labour market; $55 \%$ of this $24 \%$ were on an atypical contract; only $20.1 \%$ of these newly employed entered the labour market on a full-time permanent contract. This means that atypical contracts remain the first choice for employers. In the period 2012-2013, those on atypical contracts were more likely to remain in this type of employment (56.4\%) than to move on to full-time permanent employment (15.3\%). This is a much lower percentage than in the pre-crisis period (24\% in the $2007-2008$ period) (ISTAT 2014) - which means that, during the period observed, changes to Article 18 had no significant impact on favouring the transition to more stable employment. Moreover, given this low transition from atypical to permanent employment, it can be argued that flexible types of contract are even less likely to be a stepping-stone into permanent employment. Indeed, the rising use of 
temporary and part-time contracts is a phenomenon that can be observed in other EU economies and can be viewed as a method used by firms to deal with economic uncertainty (Garibaldi and Taddei 2013: 25).

Figure 11 Number of temporary employees in thousands 2011-2014(Q3)

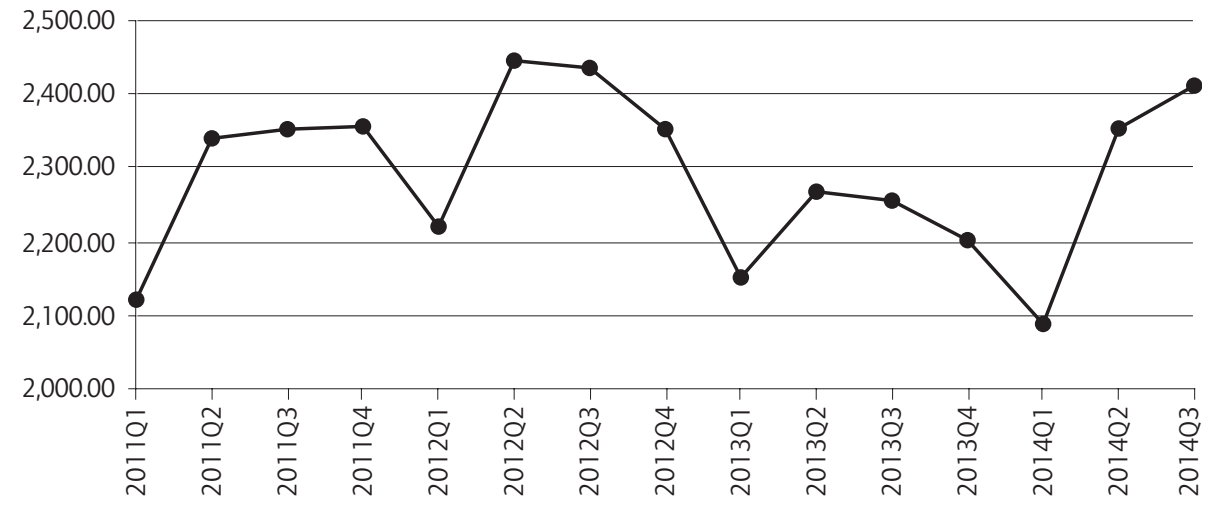

Source: Eurostat (Ifsq_egaps, Ifsq_etgaed), Data non-seasonally adjusted

Table 11 Labour market outflows by type of contract 2012 Q1- 2013 Q1 (15-64)

\begin{tabular}{|c|c|c|c|c|c|c|c|c|c|}
\hline \multicolumn{10}{|c|}{ Employment status at end of period } \\
\hline $\begin{array}{l}\text { Employment status at } \\
\text { beginning of period }\end{array}$ & $\begin{array}{l}\text { Full-time } \\
\text { Permanent }\end{array}$ & $\begin{array}{l}\text { Full-time } \\
\text { Self- } \\
\text { employed }\end{array}$ & $\begin{array}{l}\text { Part-time } \\
\text { Permanent }\end{array}$ & $\begin{array}{l}\text { Part-time } \\
\text { Self- } \\
\text { employed }\end{array}$ & Atypical & $\begin{array}{c}\text { Total } \\
\text { Employed }\end{array}$ & Unemployed & Inactive & Total \\
\hline Full-time Permanent & 89.6 & 0.9 & 2.7 & 0.1 & 1.3 & 94.5 & 2 & 3.5 & 100 \\
\hline Full-time Self-employed & 2.4 & 87.5 & 0.3 & 3.1 & 0.7 & 94 & 2.4 & 3.5 & 100 \\
\hline Part-time Permanent & 8.8 & 0.3 & 76.2 & 1 & 3.4 & 89.7 & 3.9 & 6.4 & 100 \\
\hline Part-time Self-employed & 2.9 & 18.1 & 4.9 & 55.2 & 2.1 & 83.2 & 3.7 & 13 & 100 \\
\hline Atypical & 15.3 & 1.2 & 4.8 & 0.5 & 56.4 & 78.2 & 9.5 & 12.3 & 100 \\
\hline Total Employed & 53 & 18.3 & 10.5 & 2.1 & 7.9 & 91.7 & 3.2 & 5.1 & 100 \\
\hline Unemployed & 5.1 & 2 & 2.9 & 0.9 & 13.2 & 24 & 41 & 35 & 100 \\
\hline Inactive & 1.2 & 0.8 & 0.8 & 0.5 & 2.9 & 6.2 & 8 & 85.8 & 100 \\
\hline Total & 30.8 & 10.8 & 6.4 & 1.4 & 6.4 & 55.8 & 7.5 & 36.6 & 100 \\
\hline
\end{tabular}

Note: Atypical includes project workers and employees on fixed-term contract (full-time and part-time).

Source: Istat, Rapporto Annuale 2014 



\section{Conclusion}

This paper has examined the extent to which labour market reforms in Italy in 2012 succeeded in tackling the two main problems of increasing unemployment and an increasing use of atypical contracts. In particular, the paper has looked at the impact of Law No. 92 of 28 June 2012, also known as the Fornero Reform, with a particular focus on the changes enacted in Article 18 of the Workers' Statute that regulates individual dismissals for employees on permanent contracts in firms with 15 or more employees. For two decades, Article 18 had been cited as an impediment to job creation and as a major reason for firms remaining small and preferring other forms of contractual arrangement to standard permanent contracts.

Analysis of past trends in employment in Italy does not support this assertion. Nor is it supported by changes observed in the brief period since 2012. In fact, unemployment continued to increase and employment to decrease. Temporary contracts remained the first choice for employers as the share of employees on temporary contracts remained constant and the numbers of new temporary contracts increased. The transition rate from temporary to permanent employment appeared unaffected by changes to Article 18 .

The aim of this paper has been to use published data to provide evidence for assessing the effects of reforms. It is therefore clearly impossible to assess changes introduced in 2015. However, the analysis of past reforms does engender scepticism about the importance of employment legislation for determining employment levels and for determining the balance between the use of different kinds of employment relationship. Three points can be put forward to substantiate this scepticism.

The first point concerns the significance of structural weaknesses in the Italian economy that have been aggravated by the crisis. The data presented in this paper indicate that, since 2008, the already stark differences between Northern Italy and Mezzogiorno in terms of employment and unemployment have become even greater. Southern Italy has been the most affected by the downturn in construction and by job losses in the public sector. Thus regional and sectoral structures come to appear much more significant than employment legislation - which does not differ from one region of the country to another - in determining responses to the crisis.

The second observation relates to negative trends in the Italian economy that are ignored in the context of an exclusive focus on labour-market topics. Notable among these has been the loss of high-skilled jobs, implying a slower 
transition to a high-skill economy, with potential negative effects on productivity.

The third aspect to be mentioned is the implication of employment trends throughout the whole period since the 1990s. An increase in fixed-term contracts was attributable not to the high level of protection associated with permanent contracts but, much more simply, to changes that made it possible to employ workers on a fixed-term basis. The same principle would be likely to apply with any subsequent reform. The evidence suggests that employers, given the choice, will whenever possible take advantage of legal provisions that enable them to employ on a less secure basis.

The conclusion must be that any policy solution focusing on lowering employment protection is unlikely to bring positive results. This is a highly relevant finding insofar as the Renzi government, with its Jobs Act of 2015, moved in this same direction with the abrogation of Article 18 for new employees. Any policy solution that aims to tackle the employment problems in Italy should start by addressing the structural problems in the Italian economy, meaning above all the difference between North and South and the need for a transition toward new economic activities. 


\section{References}

Anastasia B., Bragato S. and Rasera M. (2004) Dopo la grande regolarizzazione del 2002: percorsi lavorativi degli immigrati e impatto sul mercato del lavoro, in Barbagli M., Colombo A. and Sciortino G. (eds.) I sommersi e i sanati: le regolarizzazioni degli immigrati in Italia, Bologna, II mulino.

Anelli M. and Basso G. (2012) I numeri del Lavoro. http://www.lavoce.info/archives/ 26381/i-numeri-del-lavoro/

Aricò F. and Stein U. (2012) Was short-time work a miracle cure during the Great Recession? The case of Germany and Italy, Comparative Economic Studies, 54 (2), 275-297.

Bagnasco A. (1977) Tre Italie: la problematica territoriale dello sviluppo italiano, Bologna, II mulino.

Bano F. (2012) Il contratto dominante e la noia del posto fisso, Lavoro e Diritto, 26 (3-4), 497-514.

Bentolila S. and Bertola G. (1990) Firing costs and labour demand: how bad is eurosclerosis?, The Review of Economic Studies, 57 (3), 381-402.

Bodo G. and Viesti G. (1998) La grande svolta (2nd ed.), Rome, Donzelli.

Chiesi A. (2013) Corporate governance and firm ownership in Italy, in Magara $\mathrm{H}$. and Sacchi S. (eds.) The politics of structural reforms: social and industrial policy change in Italy and Japan, Cheltenham, Edward Elgar.

Clauwaert S. and Schömann I. (2013) The crisis and national labour law reforms: a mapping exercise. Country report: Italy, Working Paper 2012.04, Brussels, ETUI.

Da Roit B., González Ferrer A., and Moreno-Fuentes F.J. (2013) The Southern European migrant-based care model: long-term care and employment trajectories in Italy and Spain, European Societies, 15 (4), 577-596.

Deloitte (2012) Deloitte legal perspectives: a comparative look at dismissal costs and issues across Europe. http://www2.deloitte.com/global/en/pages/legal/articles/ legal-perspectives-dismissal-survey.html

Eurostat (2015) EU Labour Force Survey. http://ec.europa.eu/eurostat/web/ microdata/european-union-labour-force-survey

Garibaldi P., Pacelli L. and Borgarello A. (2004) Employment protection legislation and the size of firms, Giornale degli Economisti e Annali di Economia, 63 (1), 33-68.

Garibaldi P. and Taddei F. (2013) Italy: a dual labour market in transition: country case study on labour market segmentation, Employment Working Paper 144, Geneva, International Labour Office.

Graziano P. (2007) Adapting to the European Employment Strategy? Recent developments in Italian employment policy, International Journal of Comparative Labor law and Industrial Relations, 23 (4), 543-565.

Hijzen A. and Venn D. (2011) The role of short-time work schemes during the 2008-09 recession, OECD Social, Employment, and Migration Working Papers 115, Paris, OECD Publishing.

Ichino A. and Pinotti P. (2012) La Roulette Russa dell' articolo 18. http://www.lavoce. info/archives/27539/la-roulette-russa-dellarticolo-18/

ISTAT (2005) Gli stranieri in Italia: gli effetti dell' ultima regolarizzazione, Press release, Roma, Instituto nazionale di statistica. http://www3.istat.it/salastampa/ comunicati/non_calendario/20051215_00/testointegrale.pdf

ISTAT (2010) La misura dell' economia sommersa secondo le statistiche ufficiali: anni 2000-2008, Roma, Instituto nazionale di statistica. 
ISTAT (2014) Rapporto annuale 2014: la situazione del Paese, Roma, Instituto nazionale di statistica.

ISTAT (2015a) Indicatori demografici: stime per I' anno 2014, Roma, Instituto nazionale di statistica.

ISTAT (2015b) Population and households. http://dati.istat.it/?lang=en

Jessoula M., Graziano P.R. and Madama I. (2010) 'Selective flexicurity' in segmented labour markets: the case of Italian ' mid-siders' , Journal of Social Policy, 39 (4), 561-583.

Lodovici M.S. (2000) Italy: the long times of consensual re-regulation, in EspingAndersen G. and Regini M. (eds.) Why deregulate labour markets?, Oxford, Oxford University Press.

Meardi G. (2012) Employment relations under external pressure: Italian and Spanish reforms in 2010-12, Paper presented at the International Labour Process Conference, Stockholm, 27-29 March 2012.

MEF (2011) Economia non osservata e flussi finanziari: rapporto finale, Roma, Ministero dell' Economia e delle Finanze.

Myant M. and Piasna A. (2014) Why have some countries become more unemployed than others? An investigation of changes in unemployment in EU member states since 2008, Working Paper 2014.07, Brussels, ETUI.

O' Higgins N. (2011) Italy: limited policy responses and industrial relations in flux, leading to aggravated inequalities, Vaughan-Whitehead D. (ed.) Work inequalities in the crisis: evidence from Europe, Cheltenham, Edward Elgar, 321-354.

Picot G. and Tassinari A. (2014) Liberalization, dualization, or recalibration? Labor market reforms under austerity, Italy and Spain 2010-2012, Paper presented at the conference 'The welfare state in Portugal in the age of austerity', Lisbon, 9-10 May 2014.

Sacchi S. (2015) Conditionality by other means:EU involvement in Italy's structural reforms in the sovereign debt crisis, Comparative European Politics, 13 (1), 77-92.

Schivardi F. and Torrini R. (2004) Threshold effects and firm size: the case of firing costs, London, Centre for Economic Performance, London School of Economics and Political Science.

Schneider F. and Buehn A. (2012) Shadow economies in highly developed OECD countries: what are the driving forces?, IZA Discussion Paper 6891, Bonn, Institute for the Study of Labor.

Sciotto A. (2014) Pochi i 'reintegrati', ma l' articolo 18 è cosí importante, II Manifesto, 17 November 2015. http://ilmanifesto.info/pochi-i-reintegrati-ma-larticolo-18-e-cosiimportante/

Tattara G. (1999) Perchè le imprese non diventano grandi? I lacci posti dalle regole del lavoro, Economia e Società Regionale, 17 (3).

Tiraboschi M. (2012) Labour and industrial relations in recessionary times: the Italian labour relations in a global economy, Modena, Adapt University Press.

Tompson W. (2009) Italy: The Treu (1997) and Biagi (2002) reforms, in Tompson W. and Price R. (eds.) The political economy of reform: lessons from pensions, product markets and labour markets in ten OECD countries. Paris, OECD Publishing, 247-268.

Trichet J.-C. and Draghi M. (2011) Trichet e Draghi: un' azione pressante per ristabilire la fiducia degli investitori, Corriere della Sera, 29 September 2011.

http://www.corriere.it/economia/11_settembre_29/trichet_draghi_inglese_304a5 f1e-ea59-1 1e0-ae06-4da866778017.shtml 
van Hooren F.J. (2012) Varieties of migrant care work: comparing patterns of migrant labour in social care, Journal of European Social Policy, 22 (2), 133-147.

Watanabe H.R. (2015) Neoliberal reform for greater competitiveness: labour market deregulation in Japan and Italy, Industrial Relations Journal, 46 (1), 54-76.

Zingales L. and Pellegrino B. (2014) Diagnosing the Italian disease, Working Paper. http://faculty.chicagobooth.edu/luigi.zingales/papers/research/Diagnosing.pdf

All links were checked on 17.11.2015. 


\section{ETUI Working Papers}

Eliminating occupational cancer in Europe and globally

Working Paper 2015.10

Jukka Takala

The public-private sector pay debate in Europe

Working Paper 2015.08

Torsten Müller and Thorsten Schulten

The Transatlantic Trade and Investment Partnership (TTIP):

a controversial agreement and dangerous for workers

Working Paper 2015.07

Claude Serfati

Free movement of labour in Europe: a solution for better labour allocation?

Working Paper 2015.06

Béla Galgóczi and Janine Leschke

Beyond the CEE 'black box': crisis and industrial relations in the new EU member states Working Paper 2015.05

Magdalena Bernaciak

"Better Regulation": a bureaucratic simplification with a political agenda Working Paper 2015.04 / EN, FR

Éric Van den Abeele

Spain's labour market reforms: the road to employment - or to unemployment? Working Paper 2015.03

Laszlo Horwitz and Martin Myant

The European sectoral social dialogue: an uneven record of achievement?

Working Paper 2015.02 / EN, FR

Christophe Degryse

The TTIP's impact: bringing in the missing issue

Working Paper 2015.01

Martin Myant M. and Ronan O'Brien

Trade union membership retention and workplace representation in Europe.

Questions on the renewal of trade union organisation

Working Paper 2014.10

Jeremy Waddington

About the baby and the bathwater: assessing the European Platform against Poverty Working Paper 2014.09

Sebastiano Sabatiano and Bart Vanhercke 
Integrating social and environmental dimensions in public procurement: one small step for the internal market, one giant leap for the EU?

Working Paper 2014.08 / EN, FR

Éric Van den Abeele

Why have some countries become more unemployed than others? An investigation of changes in unemployment in EU member states since 2008

Working Paper 2014.07

Martin Myant and Agnieszka Piasna

These publications can be downloaded free of charge from our website.

Please visit: www.etui.org/publications 